\title{
INTERPRETACJA ZAGROŻENIA W KONTEKŚCIE POSTRZEGANIA SYGNAŁÓW OSTRZEGAJĄCYCH ORGANIZACJE
}

\author{
Bogdan Ćwik \\ Wojskowa Akademia Techniczna \\ Wydział Logistyki
}

\begin{abstract}
Streszczenie: Artykuł podejmuje problem zwiększenia skuteczności systemów ostrzegających organizację w sytuacjach niedeterministycznych. Bolączką tego typu systemów jest zjawisko tzw. „Zaskoczeń”, będące wynikiem niedostrzeżenia w porę symptomów nadchodzących zdarzeń, pomimo obecności zaawansowanych technologicznie systemów monitoringu, w tym systemów śledzenia zagrożeń. Wiele w tym obszarze zależy od skuteczności postrzegania sygnałów ostrzegawczych. Celem artykułu jest zaproponowanie uniwersalnego podejścia do interpretacji pojęcia „zagrożenie”, co powinno umożliwić bardziej skuteczne postrzeganie sygnałów ostrzegawczych.

Zastosowane w pracy metody naukowe to metoda analizy i krytyki piśmiennictwa, metoda analizy i konstrukcji logicznej oraz metody heurystyczne: metoda „nowego spojrzenia” i metoda przeniesienia analogicznego. W metody te włączono metody wnioskowania dedukcyjnego połączone $\mathrm{z}$ indukcją enumeracyjną. Rezultatem przeprowadzonych prac jest przedstawienie własnej koncepcji interpretacji pojęcia „zagrożenie”, jak również związanych z tą interpretacją modeli.
\end{abstract}

Słowa kluczowe: zagrożenie, rozwój zagrożenia, postrzeganie zagrożeń, sygnał ostrzegawczy, widoczność sygnału ostrzegawczego

DOI: $10.17512 /$ znpcz.2017.4.1.07

\section{Wprowadzenie}

Kluczowym aspektem wpływającym na jakość zarządzania organizacjami jest skuteczność monitoringu zagrożeń, generowanych przez ich otoczenie. Procesy zarząazzania tym obszarem powinny być zaliczone do podstawowych procesów związanych z funkcjonowaniem organizacji takich jak: przedsiębiorstwa, urzędy, instytucje i inne organizacje gospodarujące. „Monitoring zagrożeń ma tak długą historię, jak długa jest historia ludzkości. W każdym bowiem jej okresie ludzie w różny sposób starali się ostrzec przed grożącym niebezpieczeństwem. Nie zawsze może z pożądanym skutkiem, ale czyniono to" (Kalinowski 2003, s. 6). Systemy monitoringu są odpowiedzią na narastającą liczbę zagrożeń i związaną z tym konieczność wczesnego ich rozpoznania (Kalinowski 2003; Janik 2001).

Systemy monitoringu otoczenia współczesnej organizacji gospodarującej, jaką jest między innymi przedsiębiorstwo, muszą radzić sobie ze znaczną liczbą i różnorodnością źródel, dostarczających informacji o możliwych zagrożeniach. Przykładem jest Bolesław R. Kuc, który podaje, że na bazie kontrolingu i analiz ekonomicznych możliwe jest skonstruowanie około 300-400 różnych wskaźników 
ostrzegających (Kuc 2006, s. 263). Z kolei Elżbieta Urbanowska-Sojkin i in. wyróżniają 165 wskaźników, które mogą zawierać informacje ostrzegające dla przedsiębiorstwa (Urbanowska-Sojkin, Banaszyk, Witczak 2004, s. 204-224). Możliwość utworzenia znacznej liczby różnych wielkości i wskaźników, mogących zostać wykorzystanymi jako sygnały ostrzegające organizację, potwierdzają również wyniki prac własnych (Ćwik i in. 2007; Ćwik 2011; Ćwik 2014). W polskim piśmiennictwie widoczna jest grupa autorów, która bada ten obszar, podejmując problem odczytu i rozpoznania sygnałów zagrożeń wewnętrznych i zewnętrznych $\mathrm{w}$ przedsiębiorstwie czy też problem monitoringu otoczenia przedsiębiorstwa. Wśród wymienionych prac szczególną uwagę należy zwrócić na obszerną analizę teoretyczną i praktyczną tej problematyki przedstawioną przez Dorotę Jelonek (Jelonek 2002). Przykłady innych autorów działających w tym obszarze to: Małgorzata Tyrańska (Tyrańska 2010), Stanisław Kaczmarczyk (Kaczmarczyk 2007), Maria A. Mach (Mach 2007), Maria Drozdowicz-Bieć (Drozdowicz-Bieć 2012, s. 49-103) oraz Grażyna Gierszewska (Gierszewska 2000, s. 41-47).

Doświadczenie pokazuje, że podstawowym problemem wszelkiego rodzajów systemu monitoringu zagrożeń jest ich ograniczona skuteczność, objawiająca się dwojako - bądź niewykryciem w porę istotnych sygnałów ostrzegawczych, bądź przedwczesną i uruchamiającą niepotrzebnie zasoby reakcją zapobiegającą. Szczególnie dotkliwe jest zjawisko tzw. „zaskoczeń” w negatywnym rozwoju sytuacji, gdzie pomimo obecności zaawansowanych technologicznie i organizacyjnie systemów monitoringu, jak również zaawansowanych procedur analitycznych, nadal dochodzi do nagłych negatywnych zdarzeń, po czym po fakcie pojawiają się informacje, że symptomy tego, co się wydarzyło, widoczne były wcześniej, ale nikt nie nadał temu wystarczającej wagi, aby z wyprzedzeniem podjąć działania obronne. Jedną z przyczyn tych zjawisk są zniekształcenia i zakłócenia procesów postrzegania sygnałów ostrzegawczych. Wydaje się też, że problem ten nie jest należycie eksponowany w publikacjach dotyczących zarządzania ryzykiem czy też zarządzania bezpieczeństwem organizacji. Elementy namysłu $\mathrm{w}$ tym obszarze można znaleźć co prawda w naukach psychologicznych czy też naukach o poznaniu, ale nie są one ukierunkowane na funkcjonowanie organizacji. Podjęcie badań i studiów w tym obszarze powinno pozwolić lepiej zrozumieć mechanizmy istotnych zjawisk, zidentyfikować przyczyny powstania określonych zniekształceń i zakłóceń, a w rezultacie zwiększyć skuteczność systemów ostrzegających.

Celem głównym podjętych studiów i analiz jest poszukiwanie przyczyn ograniczonej skuteczności systemów ostrzegających organizację i zaproponowanie rozwiązań modelowych dających możliwość poprawienia tej skuteczności.

W kolejnych punktach niniejszego artykułu zostaną przedstawione wyniki własnych analiz dotyczących skuteczności postrzegania zagrożeń, wraz z wprowadzeniem pewnych własnych elementów teoretycznych, jak również związanych z tymi elementami modeli.

Zastosowane metody badawcze to metoda analizy i krytyki piśmiennictwa, obejmująca możliwy przegląd pozycji literaturowych w badanym obszarze. Druga to metoda analizy i konstrukcji logicznej oraz metody heurystyczne: metoda „nowego spojrzenia" i metoda przeniesienia analogicznego, wykorzystane przy two- 
rzeniu związanych z interpretacją pojęcia zagrożenia modeli. Natomiast przeniesienie własnych wyników prowadzonych studiów i obserwacji osób dokonujących postrzeżeń różnych sygnałów to metoda dedukcji i indukcji enumeracyjnej.

Potrzeba głębszego namysłu w tym obszarze, jak również istotne problemy metodologiczne i interpretacyjne ujawniły się w trakcie dociekań własnych, podczas prac nad tematem dotyczącym postrzegania sygnałów ostrzegawczych w sytuacjach niedeterministycznych (Ćwik 2017).

\section{Interpretacja pojęcia ,zagrożenie"}

W problematyce postrzegania sygnałów ostrzegających stwierdza się brak jednoznacznej interpretacji podstawowych pojęć. Przykładowe wypowiedzi lub sformułowania w tym obszarze to: ,identyfikacja ryzyk”, „ostrzeganie przed zagrożeniami”, „monitoring zagrożeń” czy też „stan zagrożenia”. Przedstawione w wielu źródłach definicje wydają się ogólnikowe, czasami wręcz potoczne, bazując często na wyrażeniach słownikowych. Nie podejmuje jednoznacznej definicji tych pojęć również standard ISO 31000 dotyczący systemowego zarządzania ryzykiem.

Podstawowym pojęciem związanym z postrzeganiem sygnałów ostrzegających jest pojęcie zagrożenia. Statystycznie jest to jedno z najczęściej używanych wspó1cześnie pojęć w obszarze bezpieczeństwa systemów i panuje przekonanie, że termin ten jest intuicyjnie zrozumiały i powszechnie używany. Funkcjonujące w literaturze i w wypowiedziach definicje określają to pojęcie jako: „zjawisko wywołane działaniem sił natury bądź człowieka, które powoduje to, że poczucie bezpieczeństwa maleje bądź zupełnie zanika" (Krawczyk, Ciosk, Grochowicz 2015, s. 166; Hofreiter 2012, s. 166). Taka interpretacja odnosi się zasadniczo do sfery świadomościowej danego podmiotu (człowieka, grupy społecznej, narodu), oznaczając w zasadzie określony stan umysłu człowieka lub grupy ludzi, wywołany postrzeganiem zjawisk, które oceniane są jako niekorzystne lub niebezpieczne. Pojęcie to jest również nadużywane w argumentacji naukowej i wypowiedziach eksperckich, gdzie stwierdza się powszechność występowania zwrotów typu „zagrożenie”, „stan zagrożenia” czy też „ostrzegać przed zagrożeniami”. Podstawowy problem (pytanie), jaki nasuwa się w tym miejscu, to jak ostrzegać przed czymś, co jest powszechne, czy też jak rozumieć w sytuacji powszechności zagrożeń sam zwrot „stan zagrożenia”. Problem ten pogłębia jeszcze bardziej to, że w świadomości ludzi stwierdza się obecność przeświadczenia, że cechą rzeczywistości otaczającej współczesne systemy ekonomiczne, jak również systemy społeczne jest funkcjonowanie przy ciągłej obecności zagrożeń.

Wstępnie można powiedzieć, że zagrożenie jest czynnikiem destrukcyjnie oddziałującym na dany podmiot. Trzeba zauważyć też, że nie należy utożsamiać tego pojęcia z niebezpieczeństwem, które nie jest czynnikiem, ale jest stanem, w jakim znajduje się dany podmiot. Niebezpieczeństwo jest stanem przeciwstawnym do bezpieczeństwa. Natomiast zagrożenie nie jest stanem podmiotu, ale względnie autonomicznym czynnikiem sytuacji, szkodliwie oddziałującym i mogącym wytwarzać niebezpieczeństwo, które nie jest zagrożeniem, lecz jego skutkiem. Należy zauważyć też, że zagrożenie występuje wtedy, gdy istnieje zwiększone prawdopo- 
dobieństwo naruszenia jakiejś wartości cenionej przez podmiot - np. życia, zdrowia (jego samego i jego bliskich), własności, uprawnień, pozycji społecznej, dobrego imienia, własnego dzieła, poglądów, dobrego samopoczucia lub samooceny itp. Pojęcie zagrożenia posiada również wymiar psychiczny, objawiający się tzw. poczuciem zagrożenia, który jest określonym stanem psychicznym wytwarzanym przez umysł, odznaczającym się stanem pobudzenia określonych struktur układu nerwowego i umysłu człowieka, wraz z gotowością do uruchomienia określonych scenariuszy obronnych (Świerszcz 2012, s. 69-86). I ten właśnie stan psychiczny, wyrażający się poczuciem zagrożenia, często ma wpływ na postrzeganie sygnałów ostrzegawczych.

Powyższe skłania do podjęcia bardziej pogłębionej interpretacji pojęcia „zagrożenie", stwarzającej bardziej jednoznaczne i bardziej uniwersalne podstawy teoretyczne i metodologiczne dla problematyki postrzegania sygnałów ostrzegawczych. Za zagrożenie dla danej organizacji można uważać możliwość wydarzenia się czegoś niekorzystnego, obejmującego utratę jej zdolności funkcjonalnych, rozpad lub zmianę struktury, utratę określonych cech lub powstanie innych negatywnych i nieodwracalnych zmian, tak ilościowych, jak i jakościowych. Przy czym sytuacja ta spowodowana jest obecnością niekorzystnych oddziaływań w stosunku do relacji tworzących strukturę tej organizacji lub w odniesieniu do realizowanych przez nią funkcji. Poziom tych oddziaływań jest na tyle istotny, że dalsza ich zmiana wiązać się może z przekroczeniem wartości granicznych, doprowadzających do rozwoju negatywnych zjawisk lub zdarzeń (w strukturze lub realizowanych funkcjach), do tego stopnia, że dojdzie do upadku organizacji lub nastąpią w niej nieodwracalne zmiany jakościowe.

Rozwijając ten temat, proponuje się przyjąć interpretację pojęcia „zagrożenie”, rozdzielającą je na dwie kategorie, tzn. na zagrożenie przyczynowe i na zagrożenie skutkowe. Pierwszą kategorię będą tworzyć wielkości związane z przyczyną tego, że może wydarzyć się coś negatywnego. Wielkości te można nazwać oddziaływaniami, gdzie przez oddziaływania będą rozumiane wszelkie siły fizyczne, chemiczne, mechaniczne, biologiczne, psychiczne, ekonomiczne, społeczne i inne, które wywierają negatywny wpływ na badaną organizację. Siły te można mierzyć i wyrazić ich wartość w określonej skali, stąd też mają one przeważnie charakter ilościowy. Natomiast druga kategoria to wielkości związane ze skutkami negatywnych oddziaływań, wyrażane bądź w postaci charakterystyk, obrazujących zdolność organizacji do wykonywania określonych działań, bądź wyrażające się realizacją negatywnych scenariuszy zdarzeń lub zjawisk (wybuch wojny, katastrofa komunikacyjna, wybuch gazu w kopalni, przerwanie wału przeciwpowodziowego, upadek firmy, zerwanie kontaktu przez klienta itp.). Zagrożenia skutkowe są zazwyczaj niemierzalne i można je wyrazić na ogół w skali nominalnej.

Podstawą monitorowania sygnałów o zagrożeniach jest, aby istotne oddziaływania były rozpoznane, zarówno po stronie przyczyn (m.in. mechanizmów ich powstawania czy też mechanizmów ich przenoszenia, a także mechanizmów ich rozwoju), jak również skutków, jakie mogą wywołać. Innymi słowy - wymagana jest znajomość zagrożeń przyczynowych oraz związanych z nimi zagrożeń skutkowych. 
W przypadku systemów ostrzegających podstawowym problemem jest to, co i jak obserwować oraz co i jak mierzyć, aby zapewnić skuteczne ostrzeganie przed określonymi zagrożeniami skutkowymi. Problem ten powinien przybliżyć model rozwoju zagrożenia.

\section{Model rozwoju zagrożenia}

Model rozwoju zagrożenia przedstawia przebieg zmian pewnego negatywnego oddziaływania (zagrożenia przyczynowego), które po przekroczeniu wartości granicznej doprowadzi do określonych negatywnych skutków w systemie, przede wszystkim do negatywnych i nieodwracalnych zmian jakościowych. Przedstawiono to na Rysunku 1, gdzie na osi pionowej literą $Z$ oznaczono wielkość obserwowanego oddziaływania (zagrożenia przyczynowego), a na osi poziomej czas trwania tego oddziaływania $(T)$. W normalnych warunkach system prawie zawsze funkcjonuje przy pewnym dopuszczalnym poziomie negatywnych oddziaływań, który można uważać za poziom dopuszczalny, mieszczący się w ramach obowiązujących norm. Po przekroczeniu poziomu dopuszczalnego $Z_{d p}$ poziom obserwowanego oddziaływania staje się na tyle istotny, że zaczynają się uwidaczniać pierwsze zmiany w zdolnościach do wykonywania zadań (pogarszają się charakterystyki systemu), ale w pierwszej fazie są to zmiany głównie ilościowe, które system jest w stanie skorygować. Na tym etapie można mówić o zakłóceniach, co ma miejsce wtedy, gdy istnieją warunki, siły i możliwości, aby niekorzystny bieg zdarzeń zatrzymać lub zmienić. Jednak gdy poziom tego oddziaływania przekroczy wartość graniczną $Z_{g r}$, wtedy rozpoczynają się trwałe zmiany ilościowe i jakościowe, a uwidaczniające się skutki nabierają charakteru nieodwracalnego, czyli dochodzi do trwałych zmian jakościowych. Moment ten na Rysunku 1 oznaczono jako SG (stan graniczny) i jest to skutek związany z przekroczeniem granicznej wartości tego odziaływania (GWO), po przekroczeniu którego rozpoczyna się proces destrukcji systemu, nieodwracalnie zmienia on własności, mają miejsce trwałe zmiany jakościowe. Jak widać na Rysunku 1, w tym miejscu spotykają się dwa punkty przełomowe dotyczące zagrożeń - po stronie zagrożeń przyczynowych pojawia się graniczna wartość oddziaływania GWO, a po stronie skutkowej stan graniczny systemu SG. Po przekroczeniu SG następuje realizacja określonego zagrożenia skutkowego - zaczynają się zwolnienia w firmie lub wyprzedaż majątku, woda zaczyna się przelewać przez wał przeciwpowodziowy. Początkowo realizacja zagrożenia skutkowego ma charakter częściowo odwracalny, gdzie można na nowo zatrudnić zwalnianych pracowników czy zatrzymać wyprzedaż majątku, czy też podwyższyć wał przeciwpowodziowy za pomocą worków z piaskiem, ale po pewnym czasie dochodzi do pełnej realizacji zagrożenia skutkowego, czyli do nieodwracalnych zmian jakościowych - upadku firmy, zalania terenów. 


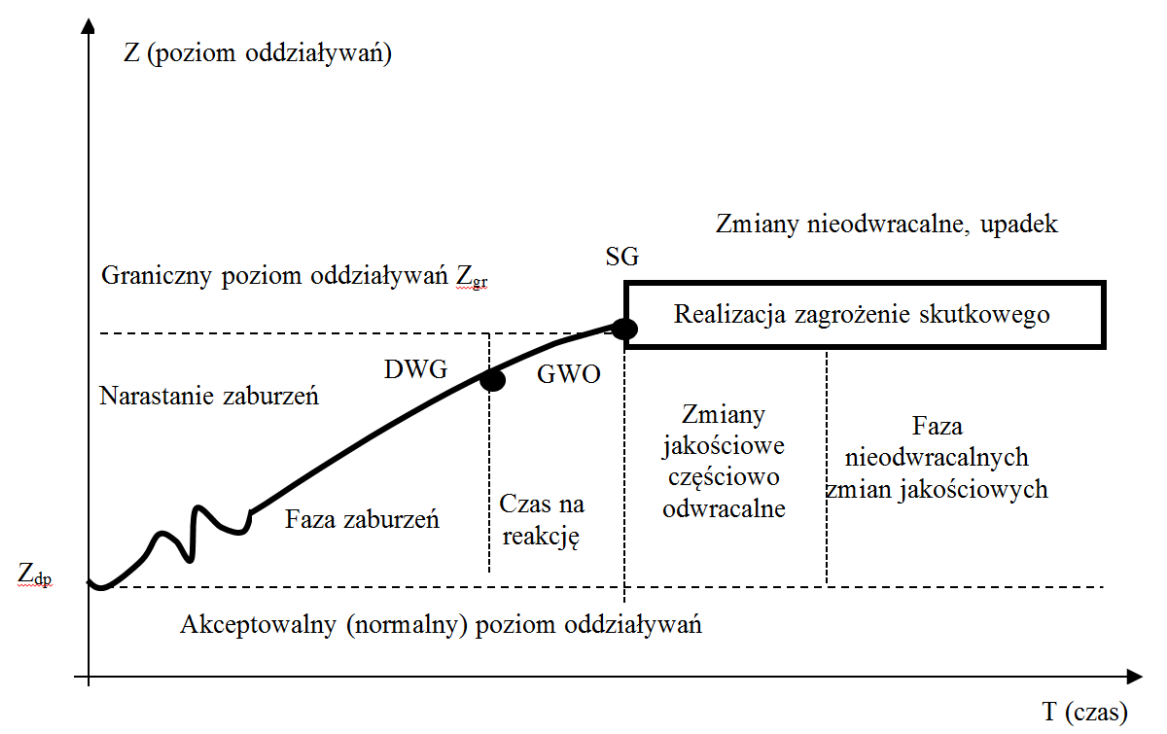

\section{Rysunek 1. Model rozwoju zagrożeń w systemie}

Źródło: Opracowanie własne

W systemach ostrzegających istotnym jest to, aby wygenerowane zostały zasoby, czy też struktury, odpowiedzialne i zdolne do tego, aby pozwolić z wystarczającym wyprzedzeniem czasowym określić moment, w którym należy podjąć działania zapobiegawcze. Moment ten na Rysunku 1 został oznaczony jako dostrzeżenie wartości granicznej oddziaływania (zagrożenia przyczynowego) DWG. Czas na reakcję, czyli czas na wygenerowanie sygnału ostrzegającego i podjęcie działań obronnych, jest wtedy równy GWO - DWG. Problemem jest jednak to, że $\mathrm{w}$ wielu $\mathrm{w}$ systemach nie zawsze można postawić znak równości pomiędzy przyczyną a skutkiem, czyli pomiędzy GWO a SG. Jest to możliwe w naukach technicznych, na przykład w próbie rozciągania próbki metalu, gdzie przekroczenie wartości granicznej siły rozciągającej jest jednoznaczne z zerwaniem próbki, czyli z przekroczeniem stanu granicznego. Innym przykładem przekroczenia stanu granicznego przez system może być poziom fali wezbraniowej w rzece, gdzie zagrożeniem przyczynowym, które podlega obserwacji, jest poziom wody w rzece, a zagrożeniem skutkowym - przelanie wody przez korpus wału, a w konsekwencji - istotne zmiany jakościowe w systemie.

$\mathrm{W}$ rozpoznaniu sygnałów ostrzegawczych ważną rolę odgrywają również subiektywne czynniki, wynikające z cech psychicznych i stanu emocjonalnego obserwatora (Ćwik 2017), które istotnie wpływają na poziom korelacji pomiędzy postrzeganiem GWO a postrzeganiem SG, co związane jest z rzeczywistą realizacją określonego zagrożenia skutkowego. Zobrazowane to zostało na Rysunku 2, na którym widoczne są dwie linie ciągłe (pogrubiona i cienka), przedstawiające wagi (subiektywnie przypisane wielkości), jakie nadaje obserwator postrzeganym zagrożeniom skutkowym i przyczynowym. Jeżeli nie byłoby zniekształceń poznawczych 
w umyśle obserwatora, to wagi zagrożeń skutkowych pokrywałyby się z wagami zagrożeń przyczynowych (linia ciągła cienka). Jednak w rzeczywistości wagi zagrożeń skutkowych postrzegane są inaczej niż wagi zagrożeń przyczynowych (linia ciągła pogrubiona). Przedstawione to zostało na Rysunku 2, gdzie przy małych wartościach zagrożeń przyczynowych może mieć miejsce sytuacja, że związane $\mathrm{z}$ nim zagrożenie skutkowe będzie miało bardzo małą wagę, a w rezultacie będzie pomijane lub nieuwzględniane przez system uwagi postrzegającego. Jednak wraz ze wzrostem poziomu zagrożenia przyczynowego wartość postrzeganego zagrożenia skutkowego rośnie i w pewnym momencie wartość postrzegana i rzeczywista zrównują się. Natomiast przy wysokich wartościach zagrożeń przyczynowych waga postrzeganego zagrożenia skutkowego wzrasta i przewyższa zagrożenia rzeczywiste. Widoczne na Rysunku 2 krzywe można nazwać krzywymi postrzegania zagrożenia skutkowego, gdzie linia cienka przedstawia teoretyczny przebieg postrzeganych wag, a linia pogrubiona, ich rzeczywisty (subiektywny) przebieg.

W praktyce każdy z postrzegających ma indywidualną linię postrzegania zagrożeń skutkowych, a jej przebieg zależy w dużym stopniu od indywidualnej postawy postrzegającego w stosunku do niebezpieczeństw (Arrow 1979, s. 57; Jajuga 2007, s. 67; Ćwik 2017, s. 53-54) lub w ujęciu psychologicznym - od tzw. różnic indywidualnych (Strelau 2015; Ćwik 2017).

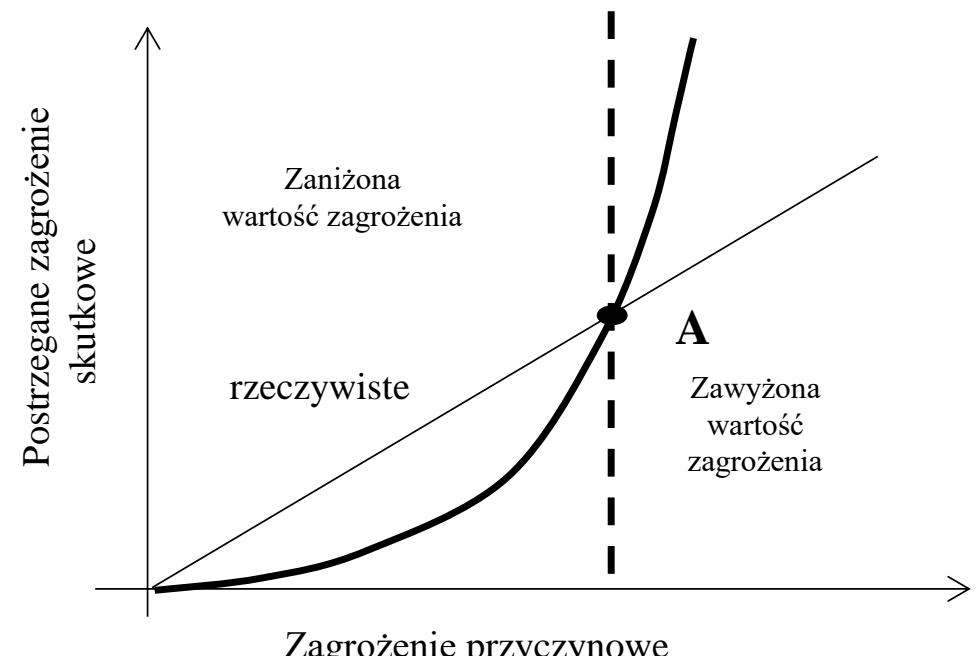

Rysunek 2. Postrzeganie zagrożeń skutkowych i przyczynowych

Źródło: Opracowanie własne

Przebieg postrzegania zagrożenia przyczynowego jest najczęściej jednoznaczny, przebiega według standardowych metodyk, gdzie realizowane sa procesy obserwacji czy też procesy pomiaru. Problemem jest waga (wielkość) postrzeganego zagrożenia skutkowego, które realizowane jest w umyśle (Ćwik 2017). Postrzeganie to może podlegać różnym zakłóceniom i zniekształceniom, co podejmuje „model wymiarów postrzegania zagrożenia skutkowego". Koncepcja takiego modelu 
została przedstawiona poniżej. Model zakłada rozważanie postrzegania zagrożenia skutkowego $W_{z} \mathrm{w}$ dziewięciu podstawowych wymiarach:

$$
W_{z}=\langle S, P, O, N, R, C, K, D, W\rangle
$$

gdzie:

$S$ - wielkość strat,

$P$ - prawdopodobieństwo,

$O-$ odległość,

$N$ - katastrofalność,

$R-$ rozmiar,

$C$ - częstość,

$K$ - kontrolowalność,

$D-$ dobrowolność,

$W$ - wyobrażalność.

Wymiary tego modelu zdecydowano się przedstawić w skali porządkowej, uwzględniając trzy poziomy wartości każdego z wymiarów:

1 - poziom nieznaczący (nieistotny);

2 - poziom częściowo znaczący (istotny);

3 - poziom silnie znaczący.

Przyjęcie takiego podziału zaproponowano $\mathrm{z}$ uwagi na fakt, że w umysłach obserwatorów dokonywana jest podobna automatyczna kategoryzacja istotności zagrożeń. Związana jest $\mathrm{z}$ tym także gotowość do uruchomienia zasobów poznawczych i energetycznych ukierunkowanych na postrzeganie sygnałów ostrzegawczych (Ćwik 2017). Na poziomie nieznaczącym rejestrowane sygnały są pomijane przez system uwagi postrzegającego, natomiast na poziomie częściowo znaczącym system uwagi jest uruchamiany, ale nie w pełni uruchamiane są wyższe procesy umysłowe, związane ze szczegółowym przetwarzaniem rejestrowanych sygnałów ostrzegawczych (Kolańczyk 1997, s. 78-102; Roman 1991, s. 12-184; Treisman 1982, s. 194-214). Z kolei na poziomie silnie znaczącym uruchamiane są wszystkie procesy umysłowe związane z przetwarzaniem sygnałów ostrzegawczych.

Wymiar „wielkość strat” określać można jako wielkość możliwych strat, wyrażanych bądź to kosztami, bądź innymi wielkościami, jak na przykład: pozycja społeczna (w miejscu pracy, w społeczeństwie, w organizacji), sytuacja w rodzinie, stan zdrowia (możliwość utraty zdrowia czy też życia), zdolność do realizacji określonych funkcji czy też utrzymania określonych struktur. Wymiar „wielkość strat” będzie zbiorem trójelementowym:

$$
S\left\{s_{1}, s_{2}, s_{3}\right\}
$$

gdzie:

$s_{l}$ - brak lub nieznaczący poziom straty niestanowiący groźby dla istnienia lub funkcjonowania danego systemu (organizacji, obiektu czy też podmiotu); $s_{2}$ - częściowo znaczący poziom straty stanowiący groźbę dla istnienia lub funkcjonowania danego systemu (organizacji, obiektu czy też podmiotu); 
$s_{3}$ - silnie znaczący poziom straty stanowiący groźbę dla istnienia lub funkcjonowania danego systemu (organizacji, obiektu czy też podmiotu), przy czym istnieje niebezpieczeństwo przekroczenia wartości granicznej, po przekroczeniu której dojdzie do trwałych zmian jakościowych lub do upadku.

Istotnym wymiarem postrzegania wielkości zagrożenia skutkowego jest prawdopodobieństwo jego realizacji. Im większe prawdopodobieństwo realizacji danego zagrożenia skutkowego, tym większa wydaje się obserwatorowi wielkość tego zagrożenia. Uwzględniając powyższe, wymiar „prawdopodobieństwo” można rozpatrywać jako zbiór złożony z następujących elementów:

$$
P\left\{p_{1}, p_{2}, p_{3}\right\}
$$

gdzie:

$p_{1}-$ brak lub niewielkie prawdopodobieństwo możliwości realizacji danego zagrożenia skutkowego;

$p_{2}$ - znacząca wielkość prawdopodobieństwa realizacji danego zagrożenia skutkowego;

$p_{3}$ - silne prawdopodobieństwo realizacji danego zagrożenia skutkowego.

$\mathrm{W}$ wielu interpretacjach przedstawione wyżej wymiary zagrożenia skutkowego, wielkości straty i prawdopodobieństwa traktowane są jako ryzyko (Ale 2009, s. 11; Appgar 2006, s. 26; Arrow 1979; Tarczyński, Moisiewicz 2001; Jajuga 2007; Kaczmarek 2006; Kuziak 2011).

Kolejnym wymiarem zagrożenia skutkowego jest „odległość”. Określany on będzie odległością (oddaleniem) w wymiarze czasowym lub przestrzennym danego zagrożenia od obserwowanego obiektu. Praktyczna obecność tego wymiaru wynika z poczucia świadomości tego, czy konsekwencje realizacji danego zagrożenia skutkowego pojawią się natychmiast, czy też mogą być odroczone w czasie, jak również czy realizacja zagrożenia będzie miała miejsce bardzo blisko postrzegającego, czy też dalej. $Z$ obserwacji wynika, że ludzie w przypadku negatywnych konsekwencji (strat) zaniżają ich znaczenie, jeżeli są one odroczone czasowo lub zlokalizowane są w dużej odległości przestrzennej. Z obserwacji wynika także, że w miarę upływu czasu zmniejsza się ujemna użyteczność wyników negatywnych.

Wymiar „odległość” można rozpatrywać jako zbiór złożony z następujących elementów:

$$
O\left\{o_{1}, o_{2}, o_{3}\right\}
$$

gdzie:

$o_{1}$ - bliska odległość czasowa lub przestrzenna, przy której u postrzegających wywoływany jest znaczący (silny) poziom poczucia utraty bezpieczeństwa, związany z istnieniem lub funkcjonowaniem danego systemu (organizacji, obiektu czy też podmiotu); przy czym istnieje niebezpieczeństwo przekroczenia wartości granicznej, po przestąpieniu której dojdzie do trwałych zmian jakościowych lub do upadku; 
$o_{2}$ - odległość czasowa lub przestrzenna, przy której u postrzegających wywoływany jest częściowo znaczący poziom poczucia utraty bezpieczeństwa, związany z istnieniem danego zagrożenia skutkowego;

$o_{3}$ - odległość czasowa lub przestrzenna jest na tyle duża, że u postrzegających niewywoływane jest poczucie utraty bezpieczeństwa lub występuje nieznaczący poziom utraty poczucia bezpieczeństwa, związany z istnieniem danego zagrożenia skutkowego.

Kolejnym wymiarem jest „katastrofalność” realizacji danego zagrożenia skutkowego. Wymiar ten związany jest $\mathrm{z}$ możliwością doznania nagłej i poważnej szkody jednocześnie przez wielu ludzi (np. na skutek jakiejś poważnej awarii lub katastrofy). Przeciwieństwem jest tzw. zagrożenie skutkowe chroniczne, które jest rozciągnięte w czasie i pociąga za sobą pojedyncze ofiary. Wybuch gazu w kopalni, katastrofa lotnicza czy zawalenie się dużego budynku są przykładami zagrożeń skutkowych katastrofalnych. Natomiast zagrożenia skutkowe takie jak wypadki samochodowe czy wypadki przy pracy są zagrożeniami skutkowymi chronicznymi. Okazuje się, że zagrożeniom katastrofalnym ludzie skłonni są przypisywać większą wartość postrzeganego zagrożenia, pomimo iż zagrożenia chroniczne w pewnym dłuższym przedziale czasowym, np. w ciągu roku, pociągają za sobą w sumie większą liczbę ofiar.

Wymiar „katastrofalność” można rozpatrywać jako zbiór złożony z następujących elementów:

$$
N\left\{n_{1}, n_{2}, n_{3}\right\}
$$

gdzie:

$n_{l}$ - niewielki poziom „katastrofalności” (zagrożenia skutkowe chroniczne);

$n_{2}$ - znaczący poziom „katastrofalności”, gdzie realizacja zagrożenia skutkowe-

go może objąć większą liczbę ofiar, dotknąć większą liczbę osób;

$n_{3}-$ silnie znaczący poziom „katastrofalności”, gdzie realizacja zagrożenia

skutkowego może nastąpić nagle, przyjąć skalę masową i objąć bardzo dużą

liczbę ofiar.

Na skuteczność postrzegania sygnałów dotyczących danego zagrożenia skutkowego ma również wpływ tzw. „rozmiar” tego zagrożenia. Im większy zasięg przestrzenny skutków tego zagrożenia, tym wydaje się ono większe i bardziej prawdopodobne. W rezultacie wymiar „rozmiar” można rozpatrywać na trzech poziomach:

$$
R\left\{r_{1}, r_{2}, r_{3}\right\}
$$

gdzie:

$r_{l}$ - niewielki zasięg przestrzenny realizacji zagrożenia skutkowego;

$r_{2}$ - znaczący zasięg przestrzenny realizacji zagrożenia skutkowego;

$r_{3}$ - duży zasięg przestrzenny realizacji zagrożenia skutkowego.

Następnym wymiarem jest częstość realizacji zagrożeń skutkowych. Istnienie tego wymiaru wiąże się z tym, iż stwierdza się, że tam, gdzie częstość negatywnych zdarzeń, na przykład wypadków, jest duża, ludzie przypisują większą wartość 
tym zagrożeniom, odczuwają też mniejszy poziom poczucia bezpieczeństwa. Istotnym problemem w tym wymiarze jest ,spostrzegana względna częstość wypadków”. Psychologowie podkreślają, że na sądy o wielkości zagrożeń istotniejszy wpływ ma subiektywnie spostrzegana przez ludzi częstość realizacji danych zagrożeń skutkowych niż rzeczywiste dane statystyczne. Na przykład wypadki, z którymi ludzie stykają się sami na co dzień lub które są powszechnie komentowane w mediach, wydają się im częstsze, bardziej prawdopodobne, a przez to wielkość postrzeganego zagrożenia skutkowego wzrasta.

Uwzględniając powyższe, wymiar „częstość” można rozpatrywać jako zbiór złożony z następujących elementów:

$$
C\left\{c_{1}, c_{2}, c_{3}\right\}
$$

gdzie:

$c_{1}$ - niewielka częstość realizacji zagrożeń skutkowych;

$c_{2}$ - znaczący poziom częstości realizacji zagrożeń skutkowych;

$c_{3}-$ silny poziom częstości realizacji zagrożeń skutkowych.

Kolejnym wymiarem postrzegania wielkości zagrożenia jest możliwość kontrolowania możliwości wystąpienia danego zagrożenia skutkowego. Wymiar ten rozumiany może być jako możliwość sterowania zdarzeniami, poprzez działania, które albo zabezpieczą przed negatywnymi skutkami, na przykład przed wypadkiem, albo zmniejszą prawdopodobieństwo lub rozmiar tych skutków, gdy wypadek już się wydarzy. Świadomość panowania nad przebiegiem sytuacji zmniejsza poziom postrzeganego zagrożenia skutkowego. W tym obszarze stwierdza się też istnienie zjawiska tzw. złudzenia kontroli, które jest widoczne dość powszechnie wśród kierowców lub sportowców, gdzie niektórzy z ich przeceniają swoje umiejętności czy też swoją sprawność.

Uwzględniając powyższe, wymiar „kierowalność” można rozpatrywać jako zbiór złożony z następujących elementów:

$$
K\left\{k_{1}, k_{2}, k_{3}\right\}
$$

gdzie:

$k_{1}-$ brak lub niewielki wpływ na przebieg realizacji zagrożeń skutkowych;

$k_{2}$ - znaczący wpływ na przebieg realizacji zagrożeń skutkowych;

$k_{3}$ - silny wpływ na przebieg realizacji zagrożeń skutkowych.

Następny wymiar, oznaczony jako „dobrowolność”, wyraża poziom swobody na dobrowolne narażanie się na zagrożenie skutkowe. Wyszczególnienie tego wymiaru wiąże się z tym, że wykonywane przez ludzi działania mogą być dwojakiego rodzaju: albo konieczne, czyli „przymusowe”, albo dobrowolne. O ile te pierwsze są często niezbędne do przetrwania jednostek lub większych zbiorowości (produkcja żywności, energii, środki transportu), to ten drugi rodzaj działań nie odgrywa tak strategicznie ważnej roli i człowiek może śmiało powstrzymywać się od ich wykonywania (np. palenia, picia alkoholu, uprawiania sportów wyczynowych). Ludzie przeceniają wielkość zagrożeń płynących z działań koniecznych, a nie doceniają wielkości zagrożeń płynących z działań dobrowolnych. Są skłonni zaakcep- 
tować nawet znacznie bardziej niebezpieczne działania dobrowolne niż działania im narzucone.

Biorąc pod uwagę powyższe, wymiar „dobrowolność” można rozpatrywać jako zbiór złożony z następujących elementów:

$$
D\left\{d_{1}, d_{2}, d_{3}\right\}
$$

gdzie:

$d_{l}$ - pełna dobrowolność na narażanie się na realizację zagrożeń skutkowych;

$d_{2}$ - częściowa dobrowolność na narażanie się na realizację zagrożeń skutkowych;

$d_{3}$ - brak dobrowolności (wymuszony udział) w narażaniu się na realizację zagrożeń skutkowych.

Kolejny wymiar postrzeganej wielkości zagrożenia to wyobrażalność przyczyn i negatywnych skutków zdarzeń. Identyfikacja tego wymiaru wynika z tego, że działania niebezpieczne mogą różnić się między sobą cechą, którą można określić jako łatwość lub trudność wyobrażania sobie i konstruowania „w umyśle” scenariusza, według którego może dojść do realizacji danego zagrożenia skutkowego. W rezultacie działania, z którymi łatwo kojarzą się określone dramatyczne scenariusze rozwoju sytuacji, są oceniane jako bardziej niebezpieczne (Ślachcińska, Kopczewski 2013). Na przykład ludzie zazwyczaj nie doceniają tych zagrożeń skutkowych, gdy na ich temat przekazuje się im suche, statystyczne informacje, nie przemawiające zbyt silnie do wyobraźni (np. o liczbie ofiar w katastrofie kolejowej). I przeciwnie, w przypadku przekazywania informacji za pomocą barwnego i sensacyjnego obrazu zdarzenia (np. sfilmowane skutki katastrofy lotniczej) ludzie odczuwają zwiększony poziom zagrożenia skutkowego, dotyczący tego zdarzenia.

Uwzględniając powyższe, wymiar „wyobrażalność” można rozpatrywać jako zbiór złożony z następujących elementów:

$$
W\left\{w_{1}, w_{2}, w_{3}\right\}
$$

gdzie:

$w_{1}$ - brak lub niewielka wyobrażalność możliwości realizacji zagrożeń skutkowych;

$w_{2}$ - częściowa wyobrażalność możliwości realizacji zagrożeń skutkowych;

$w_{3}$ - silna wyobrażalność możliwości realizacji zagrożeń skutkowych.

Wśród przedstawionych wymiarów, w których postrzegane jest zagrożenie skutkowe, każdy z osobna ma wpływ na skuteczność postrzegania. Wymiary te lokują wektor postrzeganego zagrożenia $\mathrm{w}$ trzech podstawowych obszarach możliwych poziomów zagrożeń skutkowych: zagrożenie nieznaczące, zagrożenie znaczące, silne zagrożenie. Obszary te powinny być jak najbardziej skorelowane z rzeczywistymi poziomami zagrożeń przyczynowych.

Przedstawione dotychczas wywody, dotyczące interpretacji pojęcia „zagrożenie” oraz związane z nią modele, łączą się w momencie postrzegania sygnału ostrzegawczego. Postrzeganie to łączy się z realizacją określonych procesów wykonawczych. Przebieg tych procesów związany jest z modelem sygnału ostrzegawczego. 


\section{Model sygnału ostrzegawczego}

Uzupełnieniem przedstawionych $\mathrm{w}$ niniejszym opracowaniu studiów i analiz powinien być model sygnału ostrzegawczego. Sygnałem takim może być impuls czy też bodziec lub znak, mające najczęściej charakter zaburzenia: energetycznego, chemicznego, fizycznego czy też informacyjnego. Sygnał może być wyrażony przez wartość lub obecność. Może być wyrażony indywidualnie, czyli przez pojedynczy impuls, bodziec lub znak, albo zbiorowo, przez ciąg (wektor) lub zbiór (obraz) impulsów, bodźców czy też znaków, niosących (zawierających) komunikaty ostrzegające.

Słownikowo pojęcie „sygnał” jest rozumiane jako znak mający jednoznacznie określonego nadawcę lub źródło sygnału, natomiast niemający jednoznacznie określonego adresata. Każdy sygnał niesie informację, która jest bezpośrednia lub zakodowana. Dla obserwatora zagrożeń w otoczeniu zewnętrznym lub wewnętrznym organizacji sygnały mają najczęściej postać: wskaźników, wartości charakterystyk, wartości danych ewidencyjnych, wartości danych tabelarycznych i innych. Sygnały te będą niosły informacje ostrzegające o zagrożeniach przyczynowych, jak również związane z nimi informacje o zagrożeniach skutkowych.

Uwzględniając powyższe, proponuje się, aby sygnał ostrzegawczy traktować jako znak i wykorzystać w tym celu elementy odrębnego obszaru naukowego, jakim jest teoria znaków (semiologia). Pojęcie znaku używane było już w starożytnej Grecji, gdzie stoicy traktowali znak jako związek trzech rzeczy: znaku samego (wyrazu, dźwięku mowy), treści, czyli znaczenia znaku, oraz przedmiotu realnie istniejącego (Janik 2011, s. 81). Podobne podejście przedstawił kilka wieków później Sekstus Empiryk (II-III w. n.e.), mówiąc: ,[...] trzy rzeczy są ze sobą powiązane: treść znaku, znak oraz rzecz realnie istniejąca" (Dąbska 1984, s. 97). Na tych poglądach Charles S. Pierce zbudował własną koncepcję znaku, twierdząc, że: „znak jest to coś, co występuje zamiast czegoś innego. Każdy znak ma swój przedmiot, który zastępuje, np. słowo »dom« zastępuje dom. Poza tym znak ma swą materialną jakość, tzn. pewną postać zmysłową, w jakiej go możemy obserwować, np. znaki pisma czy dźwięki. [...]. Poza tym musi istnieć umysł interpretujący dany znak" (Buczyńska 1966, s. 58). I z takiego rozumowania wyłoniła się u Peirce'a „triadyczna koncepcja znaku” (Janik 2011, s. 81-115). Peirce pisał o tym następująco: „Definiuję znak jako cokolwiek, co z jednej strony jest tak zdeterminowane przez pewien obiekt, a $\mathrm{z}$ drugiej tak determinuje określoną ideę $\mathrm{w}$ umyśle człowieka, że ta druga determinacja, którą nazywam interpretantem znaku, jest wskutek tego pośrednio zdeterminowana przez tenże obiekt. Znak zatem występuje w triadycznej relacji ze swym obiektem, gdzie interpretant ma naturę myśli, w sensie logicznym. Znak jest medium, pośrednikiem, który nie przesłania rzeczy realnie istniejącej. Dzięki znakowi rzecz jest obecna dla umysłu" (Janik 2011, s. 89).

Uwzględniając powyższe, przyjęto, że sygnał ostrzegający organizację również jest znakiem i że również ma strukturę triadyczną zawierającą trzy składowe: interpretację, reprezentację i oddziaływanie, jako właściwa treść postrzeganego znaku (Rysunek 3). 


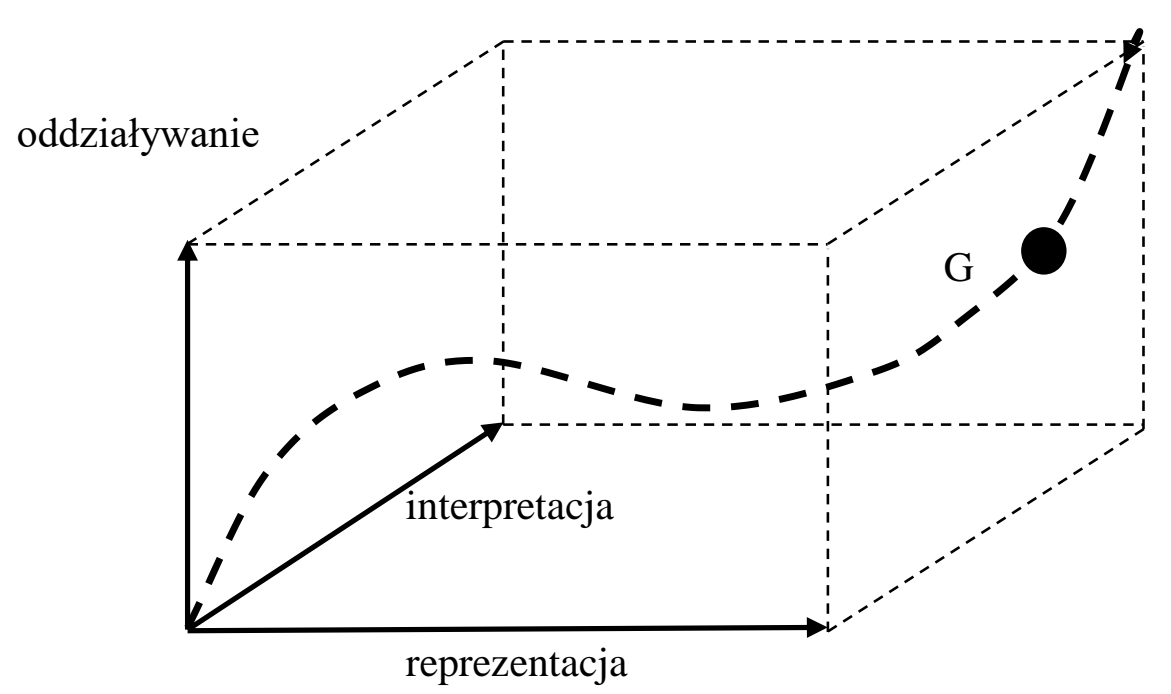

\section{Rysunek 3. Trójwymiarowy model sygnału ostrzegawczego}

Źródło: Na podstawie (Hiltunen 2008)

W modelu takim treść znaku jest wyrażana przedstawianym w odpowiedniej skali poziomem określonego oddziaływania, najczęściej niekorzystnego. Natomiast obserwator nie odczytuje bezpośrednio tego oddziaływania, lecz jego reprezentację. Na przykład bezpośrednio odczytane przez obserwatora kreski na termometrze będą reprezentacją, a skorelowanym $\mathrm{z}$ tą reprezentacją oddziaływaniem (treścią znaku) będzie temperatura. $Z$ tym że wymaga to jeszcze interpretacji, gdyż odczytana na przykład wartość 40 stopni Celsjusza, może świadczyć o istotnym zagrożeniu w przypadku temperatury ciała człowieka lub temperatury otoczenia, ale w systemie chłodzenia silnika spalinowego lub też w systemie ogrzewania domu może świadczyć o ich prawidłowym działaniu. Podobnie będzie przy odczytywaniu reprezentacji innych oddziaływań: ciśnień, częstotliwości, napięć lub natężeń prądu elektrycznego i innych. Przedstawiona na Rysunku 3 linia przerywana przedstawia trajektorię widoczności znaku, gdzie widoczność ta to nie tylko widoczność samego oddziaływania, co domyślnie jest przyjmowane w wielu współczesnych systemach monitoringu zagrożeń. A to na właśnie na takiej trajektorii odczytywana jest przez obserwatora graniczna wartość oddziaływania GWO, na podstawie której podejmuje on decyzję o uruchomieniu bądź wstrzymaniu działań obronnych związanych z danym zagrożeniem. Obserwator powinien mieć świadomość, że rzeczywista widoczność sygnału ostrzegawczego przebiega wzdłuż trzech składowych, obejmując odziaływanie, jego reprezentację i interpretację. Bardziej szczegółowa argumentacja została zawarta w pracy Skuteczność rozpoznania sygnałów... (Ćwik 2016, s. 249-270). O skuteczności postrzegania sygnału ostrzegawczego decydują dwie składowe znaku: „reprezentacja”, związana z bezpośrednim odczytem określonych wartości, oraz składowa „interpretacja”, związana z przebiegiem określo- 
nych procesów wykonawczych głównie w umyśle człowieka zachodzących (Ćwik 2017, s. 80-124). Wszelkie zakłócenia lub zniekształcenia tych procesów wykonawczych mogą istotnie wpłynąć na skuteczność wydawanych ostrzeżeń.

\section{Podsumowanie}

Rezultatem przeprowadzonych rozważań jest wykazanie, że w postrzeganiu sygnałów ostrzegawczych istotne jest rozdzielenie, czy postrzegany jest skutek, czy przyczyna. Dla odróżnienia proponuje się przyjęcie określeń: „,zagrożenie przyczynowe” i ,zagrożenie skutkowe”. Zagrożenie przyczynowe należy mierzyć bezpośrednio albo poszukać skorelowanego z nim tzw. symptomu. Z pomiarem wielkości zagrożenia przyczynowego wiąże się składowa sygnału ostrzegawczego, jaką jest reprezentacja. Pomiar ten polega na odczytaniu wartości związanych $\mathrm{z}$ reprezentacją znaku, po czym następują procesy wykonawcze realizowane w strukturach umysłu i systemu nerwowego obserwatora, co odzwierciedla składowa interpretacja w modelu sygnału ostrzegawczego. Wzdłuż składowej „interpretacja" zachodzą procesy poznawcze związane $\mathrm{z}$ odczytem zagrożenia skutkowego i związanego $\mathrm{z}$ nim zagrożenia przyczynowego, $\mathrm{z}$ tym że odczyt tych zagrożeń nie jest jednoznaczny (Rysunek 2). Szczególnym zakłóceniom i zniekształceniom podlega odczyt i poznanie zagrożenia skutkowego, które może przebiegać w dziewięciu różnych wymiarach.

Przedstawiona interpretacja pojęcia „zagrożenie” i związane z nią modele powinny przyczynić się do osiągnięcia postawionego we wstępie celu niniejszego opracowania. Wyniki przedstawionych prac są wstępną propozycją podejścia do zagadnienia, którą można dalej rozwijać. Wydaje się, że takie podejście porządkuje problematykę, pozwala ująć problem z perspektywy systemowej, stwarza też korzystne warunki do opracowania skutecznej metodologii pomiaru i oceny zagrożeń. Podejście to stara się też wyjaśnić przyczyny zakłóceń i zniekształceń w postrzeganiu zagrożeń.

Przedstawioną w niniejszym opracowaniu koncepcję można potraktować jako zalążek nowego obszaru badawczego, który można próbować nazwać teorią zagrożenia. Podział na zagrożenia przyczynowe, mierzalne i dające się wyrazić w skali pomiarowej, oraz skutkowe, dające się wyrazić jedynie w skali nominalnej, stwarza podstawy do skuteczniejszego uporządkowania metodyk monitorowania zagrożeń, organizacji systemów wczesnego ostrzegania czy też systemów zarządzania ryzykiem.

\section{Literatura}

1. Ale B. (2009), Risk: An Introduction, the Concepts of Risk, Danger and Chance, Routledge, Oxon.

2. Appgar D. (2006), Risk Intelligence: Learning to Manage What We Don't Know, Harvard Business School Press, Boston.

3. Arrow K.J. (1979), Eseje z teorii ryzyka, PWN, Warszawa.

4. Buczyńska H. (1966), Peirce, Wiedza Powszechna, Warszawa. 
5. Ćwik B. (2016), Skuteczność rozpoznania sygnałów o zagrożeniach - aspekty teorii znaków, [w:] Żylińska J., Przychocka I., Filipowska-Tuthill M. (red.), Współczesne wyzwania nauk społecznych i ekonomicznych, Uczelnia Techniczno-Handlowa im. Heleny Chodkowskiej w Warszawie, Warszawa, s. 230-241.

6. Ćwik B. (2017), Postrzeganie sygnałów ostrzegajacych organizację w sytuacjach niedeterministycznych, WAT, Warszawa.

7. Ćwik B. i in. (2007), Koncepcja modelu zarządzania strategicznego Stużba Celna, praca naukowo-badawcza WSCiL, temat S.1.2., etap II, Warszawa.

8. Ćwik B., Telep J. (2014), Koncepcja systemu wczesnego ostrzegania przed zagrożeniami dla autopoietycznego systemu organizacyjnego, funkcjonujacego $w$ dynamicznym, rozproszonym $i$ wieloszczeblowym środowisku informatycznym, praca badawcza UTH, temat KMWCiL (Z.5), Warszawa.

9. Ćwik B., Telep J., Telep T. (2011), Procesy decyzyjne $w$ wirtualnych systemach logistycznych - aspekt systemu wczesnego ostrzegania $w$ zarzadzaniu wirtualnym systemem logistycznym, praca badawcza WSCiL, temat KMWCiL (Z.1.1), Warszawa.

10. Dąbska I. (1984), Wprowadzenie do starożytnej semiotyki greckiej, Zakład Narodowy im. Ossolińskich, Wrocław.

11. Drozdowicz-Bieć M. (2012), Cykle i wskaźniki koniunktury, Poltext, Warszawa.

12. Gierszewska G. (2000), Zarządzanie strategiczne, Wydawnictwo Wyższej Szkoły Przedsiębiorczości i Zarządzania im. L. Koźmińskiego, Warszawa.

13. Hiltunen E. (2008), The Future Sign and Its Three Dimension, „Futures”, Vol. 40, No. 3, s. 247-260. DOI: 10.1016/j.futures.2007.08.021

14. Hofreiter L. (2012), Wstęp do studiów bezpieczeństwa, Oficyna Wydawnicza AFM, Kraków.

15. Jajuga K. (2007), Zarzadzanie ryzykiem, Wydawnictwo Naukowe PWN, Warszawa.

16. Janik P. (2001), Monitoring i prognozowanie sytuacji kryzysowych w zakresie klesk żywiotowych, katastrof technicznych i innych zagrożen, AON, Warszawa.

17. Janik P. (2011), Koncepcja przekonania w ujęciu semiotyczno-pragmatycznym: Charles S. Peirce, Wydawnictwo WAM, Kraków.

18. Jelonek D. (2002), Systemy komputerowego wspomagania monitorowania otoczenia przedsiębiorstwa, Wydział Zarządzania Politechniki Częstochowskiej, Częstochowa.

19. Kaczmarczyk S. (2007), Zastosowania badań marketingowych: zarządzanie marketingowe i otoczenie przedsiębiorstwa, PWE, Warszawa.

20. Kaczmarek T.T. (2006), Ryzyko i zarzadzanie ryzykiem. Ujęcie interdyscyplinarne, Difin, Warszawa.

21. Kalinowski R. (2003), Monitorowanie zagrożeń, Wydawnictwo Akademii Podlaskiej w Siedlcach, Siedlce.

22. Kolańczyk A. (1997), Uwaga w procesie przetwarzania informacji, [w:] Materska M., Tyszka T. (red.), Psychologia i poznanie, Wydawnictwo Naukowe PWN, Warszawa, s. 79-98.

23. Krawczyk A., Ciosk K., Grochowicz B. (2015), Ryzyko i zagrożenie w polu elektromagnetycznym - krytyczna analiza pojęć, „Przegląd Elektrotechniczny”, R. 91, nr 1, s. 166-198. DOI: $10.15199 / 48.2015 .01 .36$

24. Kuc B.R. (2006), Kontroling narzędziem wczesnego ostrzegania, Wydawnictwo Menedżerskie PTM, Warszawa.

25. Kuziak K. (2011), Pomiar ryzyka przedsiębiorstwa. Modele pomiaru i ich ryzyko, Wydawnictwo Uniwersytetu Ekonomicznego we Wrocławiu, Wrocław.

26. Mach M.A. (2007), Temporalna analiza otoczenia przedsiębiorstwa: techniki $i$ narzędzia inteligentne, Wydawnictwo Akademii Ekonomicznej im. Oskara Langego, Wrocław.

27. Roman Z. (1991), Uwaga i pamięć, Wydawnictwa Uniwersytetu Warszawskiego, Warszawa.

28. Strelau J. (2015), Różnice indywidualne: historia, determinanty, zastosowania, Wydawnictwo Naukowe Scholar, Szkoła Wyższa Psychologii Społecznej, Warszawa. 
29. Ślachcińska E., Kopczewski M. (2013), Ochrona i odporność kluczowych zasobów infrastruktury krytycznej, [w:] Kopczewski M., Grzelczak-Miłoś I., Walachowska M. (red.), Paradygmaty badań nad bezpieczeństwem. Zarzadzanie krytyczne $w$ teorii i praktyce, WSB, Poznań, s. 603-617.

30. Świerszcz K. (2012), Poznanie naukowe wobec problemów rozwoju gospodarczo-cywilizacyjnego, „Przedsiębiorczość i Zarządzanie”, t. 13, z. 3, s. 69-83.

31. Tarczyński W., Mojsiewicz M. (2001), Zarządzanie ryzykiem, PWE, Warszawa.

32. Treisman A. (1982), Perceptual Grouping and Attention in Visual Search for Features and for Objects, „Journal of Experimental Psychology: Human Perception and Performance”, Vol. 8, No. 2, s. 194-214. DOI: 10.1037//0096-1523.8.2.194

33. Tyrańska M. (2010), Wykorzystanie metod analizy strategicznej w przedsiębiorstwie, Wydawnictwo Uniwersytetu Ekonomicznego, Kraków.

34. Urbanowska-Sojkin E., Banaszyk P., Witczak H. (2004), Zarządzanie strategiczne przedsiębiorstwem, PWE, Warszawa.

\title{
INTERPRETATION OF THE THREAT IN THE CONTEXT OF PERCEIVING THE WARNING SIGNALS IN THE ORGANIZATION
}

\begin{abstract}
The article raises the problem of increasing the effectiveness of systems that warn organizations in non-deterministic situations. The phenomenon of so-called "surprises", which is the result of not being aware of the symptoms of upcoming events, despite the presence of technologically advanced monitoring systems, including threat tracking systems. Much in this area depends on the perception of warning signals. The aim of this article is to propose a universal approach to interpretation of the concept of threat, what should enable more effective perception of warning signals.

Research methods used in the work are the method of analysis and criticism of the literature, the method of analysis and logical construction and the heuristic method: the "new look" method and the analogue transfer method. These methods include deductive inference methods combined with enumerative induction. The result of the work is to present the concept of the interpretation of the concept of threat as well as the interpretation of the model.
\end{abstract}

Keywords: threat, threat development, perception of threats, warning signal, visibility of the warning signal 